\title{
PROTEST AND SOCIAL CREATIVITY: AN ART AND ACTIVIST NETWORK FURTHERS DEBATE ON PROBLEMS OF URBAN LIVING SPACE
}

Original scientific paper Submitted: 19. 6. 2018. Accepted: 19. 10. 2018.

DOI: $10.15176 /$ vol55no208

UDK 316:165.744 331.342:366.764(430-21München) $7.038 .531(430)$

\section{JOHANNES MOSER \\ Institute for European Ethnology and Cultural Analisys, Munich}

\begin{abstract}
The contribution originates from the project "habitation and habitation politics" in Munich, a subproject of the DFG research group "urban ethics". Using the example of the Goldgrund art and activist network, it demonstrates how middle-class actors react to the tense real estate and rental market in Munich with different forms of protest. Among other things, Goldgrund designed fictitious real estate projects, was active against the privatization of public property and buildings and founded the social cooperative Bellevue di Monaco. The article analyzes this phenomenon at different levels. First, it focuses on the role of the middle class in such activist movements and asks what motivates its involvement. Then, the "subversive" practices of this form of protest are analyzed. Furthermore, it looks into the ethical arguments in this network which strongly emphasize good life in the city and empathic urbanism. Finally, these activist endeavors and the foundation of a social cooperative resulting from it can be interpreted as a form of "social creativity" in David Graeber's sense, which contributes to the creation of new social forms and institutional arrangements.
\end{abstract}

Keywords: real estate market, protest movements, middle class, social creativity, urban ethics, Munich

\section{INTRODUCTION ${ }^{1}$}

The Goldgrund artist and activist network went public with a "subversive" campaign in 2012. Calling themselves "Goldgrund Immobilien Organisation" and acting as a fictitious

${ }^{1}$ I thank the reviewers for their helpful comments and apologize that I could not follow all of them. 
real estate company, they launched a residential project by the name of "L'Arche de Munich" at the Münchner Freiheit - right in the middle of the popular Schwabing district, where, as the advertisement put it, confident citizens, colorful artists and internationally renowned professors dominated the streetscape. Goldgrund claimed to be planning a self-contained city quarter for so-called high performers to let Schwabing's new center emerge. They said they could guarantee lasting security and comprehensive comfort in an attractive "compact community". The advertisement further announced that, overlooking the Siegestor and the Feldherrenhalle, professional visions could be realized, while in the evenings, the vibrant city could be enjoyed "in cinemascope" from the strictly private Freiheit plaza. ${ }^{2}$

The discussion of Goldgrund which is presented in this article is part of the research project "Habitation and habitation politics in Munich" of the DFG research group "Urban ethics". ${ }^{3}$ Even though the topic of habitation constitutes a problem affecting large parts of the population, particularly in prosperous cities, we focus in our subproject on the middle class and their modes of reaction to increasing rent and real estate prices. In recent times, an intensive discourse about the middle class has begun both in the social sciences and the arts sections of quality newspapers (i.e. Bude 2011; Frank 2013; Koppetsch 2013), and it should be noted that most of the population in Germany consider themselves as middle class even if this self-assessment does not necessarily correspond to their economic, cultural and social capital in the sense of Pierre Bourdieu. ${ }^{4}$ When looking at income, it is assumed that approximately $20 \%$ of Germans are situated above and $25 \%$ below the middle class, while the middle class as a whole shrank from $62 \%$ in 2000 to 54\% in 2006 (Grabka and Frick 2008: 101). In addition to this economic classification, it can be stated that the middle class includes particularly those social backgrounds which can shape public debates. At first sight, this is not very remarkable, because, as Cornelia Koppetsch, following Stephan Lessenich, states, after World War II, the middle class has been upgraded to the style-forming societal milieu whose lifestyles, values and behaviors became binding for the society as a whole (Koppetsch 2013: 20). These days, however, it is the uncertainty of an increasingly vulnerable middle class that is discussed everywhere. Heinz Bude has argued this particularly regarding education (Bude 2011), Susanne Frank regarding the current housing crisis (Frank 2013) and Cornelia Koppetsch discusses the modes of reaction of the endangered middle to the current societal situation in Germany overall (Koppetsch 2013). The example discussed in this article is an excellent match for these debates, as becomes apparent when looking at other members of the Goldgrund

\footnotetext{
${ }^{2}$ This paragraph refers to the website http://www.goldgrund.org/schwabing/ (Accessed March 19, 2016).

${ }^{3}$ For details on the interdisciplinary research unit, subprojects and researchers involved, see http://www. en.urbane-ethiken.uni-muenchen.de/index.html

${ }^{4}$ How far self-assessment and social "reality" can diverge is shown by a poll cited by Cornelia Koppetsch, according to which, on a top-to-bottom scale of 1 to 10, executives rated themselves as 6.6 while unskilled laborers still located themselves at 4.6 (Koppetsch 2013: 179).
} 
network. ${ }^{5}$ These include Till Hofmann, a small arts entrepreneur, Alex Rühle, an arts section editor of the Süddeutsche Zeitung, and Christian (Grisi) Ganzer, a director and filmmaker; there are many committed individuals from the Munich arts and culture scene around this core of founders, such as Mehmet Scholl (former footballer), Sportfreunde Stiller (German rock band), Brigitte Hobmeier (actress), Gerhard Polt (cabaret artist), Markus Rosenmüller (director), Luise Kinseher (cabaret artist), Dieter Hildebrandt (late cabaret artist) and Keno Langbein (musician). ${ }^{6}$

Munich is one of those prosperous cities in Germany in which the housing market is under massive pressure, where rents are increasing rapidly, and property is only available at horrendous prices. According to the current rent index of December 2016, rent per square meter in Munich currently stands at between 17.20 and 21.33 Euro,? respectively, 20.15 and 24.19 Euro, ${ }^{8}$ while the sale price for property is between 7,116 and 7,341 Euro per square meter. ${ }^{9}$ This development remained largely unnoticed for a long time, perhaps because Munich is a wealthy city with a large middle class which could still cope under the conditions given. The Goldgrund example shows, however, that there has been a civil society protest against this development ${ }^{10}$ for some years now, which is conducted, among others, by means of arts activism which ties on to the fundamental considerations of our research group regarding the question of the connection between ethical subjects and urbanity and social creativity.

\section{IRONIC AND SUBVERSIVE ACTIVISM}

In the Schwabing district mentioned above, the advertisement promised prestigious and luxurious town apartments equipped with extremely lavish floor plans and uncompromising clarity. Goldgrund further advertised its apartments as being of a classic modern look, with certified tropical timber floors, a Japanese roof garden and integrated premium head offices, while a maximum of privacy and security was guaranteed by separate entrances for the residents and their discreet facility and subsistence management. ${ }^{11}$ The exuberant tone of the advertisement continued in its description of the location, promising the best of

5 The members of the Goldgrund network do not operate explicitly with the term "middle class" for themselves but it becomes clear implicitly through all their actions and statements that they see themselves as members of the middle class.

${ }^{6}$ The names of the persons mentioned - with the exception perhaps of the famous footballer Mehmet Scholl - will be unknown to an international audience. Nevertheless, I would like to mention them, because they illustrate the line-up of the artistic-intellectual environment of this network.

7 http://www.wohnungsboerse.net/mietspiegel-Muenchen/2091 (Accessed December 19, 2016).

${ }^{8}$ https://www.immowelt.de/immobilienpreise/muenchen/mietspiegel (Accessed December 19, 2016).

${ }^{9}$ http://www.wohnungsboerse.net/immobilienpreise-Muenchen/2091 (Accessed December 19, 2016).

10 There are, of course, several other initiatives and activists from a political spectrum ranging from a leftist scene into the center of society. Goldgrund, however, is the most publicity-effective and most well-connected group.

${ }^{11}$ http://www.goldgrund.org/features/ (Accessed March 21, 2016). 
city and country living right next to Leopoldstraße, while listening to the patter of tasteful water gardens. Residents would be proud citizens of a bustling metropolis and, at the same time, live in a premium oasis of luxury, work in the heart of the city by day and sit under the plaza arcades at night. ${ }^{12}$

Under the headline "gentle fication", the long-established residents are supposedly also considered and offered the security of an apartment close to their place of work and a corresponding job. Goldgrund stated that they were aware of their great social responsibility in an urban setting and, thus, offered not only exquisite residences for the sophisticated, but also gave the residents of the surrounding areas generous opportunities for development as each of their premium objects generated new employment in the areas of subsistence management, security and domestic responsibility. Goldgrund claimed to have established itself as one of the most reliable providers of Munich's dynamic service sector and to offer all their employees cleverly designed apartments in the lower sections of the L'Arche de Munich, where intelligent use of space, compact architecture, affordable rent and close proximity to the employer guaranteed optimum workflows for both sides. Through this concept of sustainable real estate management, the advertisement said, Goldgrund would save the resource constituted by the established population and allow them to remain in their familiar environment. ${ }^{13}$

The project was activated in an online real estate portal, flyers were distributed and a fictitious sales office was set up in a gallery. ${ }^{14}$ Even though a close look at the style of the texts and the planned location of the project (which would not be possible to realize in the location given because public spaces, such as the central traffic junction for public transport at the Münchner Freiheit, would have to be abandoned) immediately reveals that it must be a satire, the campaign called different groups to action. Several real estate agents, for instance, proffered their services to sell the apartments on offer. Furthermore, there were people interested in the service sector jobs, the chairperson of the district council was bombarded with phone calls and, supposedly, upset parents at the neighboring primary school even collected signatures against the project. ${ }^{15}$ Even the head of the municipal planning and building control office in charge reacted in writing to the project and pointed out the specific regulations to which such real estate projects in Munich are subject. ${ }^{16}$

\footnotetext{
12 http://www.goldgrund.org/die-lage/ (Accessed March 22, 2016).

${ }^{13}$ http://www.goldgrund.org/ein-herz-fur-munchner/ (Accessed March 22, 2016).

${ }^{14}$ See Anna Günther: Der ganz normale Wohn-Wahnsinn. In: Süddeutsche Zeitung, May 26/27/28, 2012, R3. The production of flyers and the use of advertising slogans are especially reminiscent of the strategies of so-called "adbusting" or "subvertising", in which advertisements are defamiliarized or reinterpreted (Beaugrand and Smolarski 2016: 6ff.).

$15 \mathrm{lbid}$.

${ }^{16}$ http://www.goldgrund.org/wp-content/uploads/2012/05/2012.05.25-Goldgrund.pdf (Accessed March 21, 2016).
} 
The spectacular project sketched here presents a critical position on the gentrification of Munich, which has, incidentally, been affecting many quarters for decades, but it was merely the beginning of further appearances by Goldgrund. The activists campaigned for the preservation of a sports ground at the Glockenbachwerkstatt in the middle of Munich's inner city in the fall of 2012. This sports ground was earmarked to fall victim to new development plans because the houses at Müllerstraße 2-6 were deemed only fit for demolition by the city of Munich, and a residential building was to be constructed which would also require the space of the sports ground. A large civil society alliance, which was predominantly driven by Goldgrund, formed against this project. Goldgrund again launched an advertisement for a luxurious project on the real estate website Immobilienscout and wrote that the city had let a valuable piece of land at the Glockenbachwerkstatt lie idle for years and had allowed children to pointlessly play football on it, with the taxpayer footing the bill. Now, however, they claimed, their sensible approach to increasing urban density created new value in the highly sought-after real estate market of the Gärtnerplatzviertel.17 Many prominent Munich citizens participated in the protests for the preservation of the sports ground. Lately, since this campaign, the network around Goldgrund has gathered pace and created many headaches for the city authorities.

\section{THE FOUNDING OF A SOCIAL COOPERATIVE}

In the conflicts around the sports ground, the houses at Müllerstraße 2-6 also came into focus of the activists, as these constituted the basis for this dispute. When Goldgrund and cooperating groups discovered that the buildings were vacant and supposedly could no longer be renovated, they started their next spectacular campaign. With prominent supporters, they dressed up as gorillas and renovated an apartment in one of the buildings earmarked for demolition. As these houses were owned by the city of Munich, the event caused considerable stir, especially as vacant apartments are hard to justify under the conditions of an acute housing shortage in Munich. Consequently, there was an immediate political debate in which the CSU, as the largest opposition fraction, attacked the then redgreen (SPD in coalition with the Greens) city government ${ }^{18}$ and put the mayor, Christian Ude, on the spot. When Goldgrund then proceeded to commission an architect and an energy consultant to investigate the house at Müllerstraße 6 and they found that it was possible to renovate it with manageable effort, the city of Munich was irretrievably on the defensive. The preservation of the sports ground and the restoration of the houses play an important role and have a symbolic meaning for many of the activists and inhabitants of the inner city of Munich to which the houses in the Müllerstraße belong. This area, which

17 http://www.muenchenblogger.de/politik/immobilie-an-der-glockenbachwerkstatt-kampf-um-den-bolzplatz (Accessed December 15, 2016).

${ }^{18}$ Munich has been governed by a coalition between the CSU and the SPD under an SPD mayor, Dieter Reiter, since 2014. 
was historically inhabited by craftsmen, officials and people from the middle class, had been in a bad state since the middle of the $20^{\text {th }}$ century. Since then, workers and migrants mostly populated this quarter until the end of the $20^{\text {th }}$ century when a gentrification process started. Rents and prices of apartments skyrocketed and the structure of the area changed rapidly. There is a fear that sooner or later the inner city will belong totally only to the rich and that is the reason why this protest was so successful.

Finally, the activities culminated in efforts to realize a social cooperative project by the name of "Bellevue di Monaco" in the vacant buildings in Müllerstraße. The project envisions a house of integration which is to become a transcultural place of encounter in which young refugees and families live, and the creation of artist studios, workshops and rehearsal rooms for the cultural scene. In addition to Goldgrund, the project is backed by renowned youth service sector providers and other stakeholders from the arts and culture scene in Munich. Referring to a popular Munich slogan, the initiators claimed that it was to become a place of welcome in the heart of the "city with a heart." 19 In the words of Goldgrund, as citizens of a liberal global city, Munich residents must ensure that the people they accommodate have a perspective of becoming part of the city's society. ${ }^{20}$ As part of this effort, Goldgrund and the other activists said they wanted to stand up for the protection of asylum seekers and counter racist tendencies. ${ }^{21}$ The endeavor was presented to the mayors and councilors and promoted as a lighthouse project which was comparable to the "Integrationshaus" in Vienna or the "Grandhotel Cosmopolis" in Augsburg. The policymakers could not or did not want to refuse themselves the positive public (self-)representation. Therefore, the project was approved by the city of Munich, and the respective property and 1.7 million Euros in reconstruction cost grants was given to the non-profit social cooperative "Bellevue di Monaco."22

\section{SOME NOTES ON RECENT MIDDLE-CLASS DISCUSSIONS IN GERMANY}

The Goldgrund example contains several aspects which are worthy of discussion for cultural studies. To do so, I would like to fistly take up a social science discussion of the middle class. The authors mentioned at the beginning of this article see different forms of dealing with the real or imagined threats to the social situation of the middle class.

\footnotetext{
${ }^{19} \mathrm{http}: / /$ www.sueddeutsche.de/muenchen/projekt-bellevue-di-monaco-zuhause-im-herzen-muenchens-1.2054076 (Accessed December 18, 2016).

${ }^{20} \mathrm{http} / / /$ blog.initiativgruppe.de/2014/09/10/migration-aktuell-39-16-07-10-09-2014/ (Accessed December 18, 2016).

${ }^{21}$ http://www.sueddeutsche.de/muenchen/projekt-bellevue-di-monaco-zuhause-im-herzen-muenchens-1.2054076 (Accessed December 18, 2016).

22 It should at least be mentioned here that the city had planned to erect 20 social housing apartments in this location. Neither a luxury renovation nor a luxury new development was being discussed.
} 
Cornelia Koppetsch, for example, recognizes a return to conformity. Whereas during welfare capitalism, it was precisely the milieu of the middle which brought forth the new social movements which acted progressively, alternatively and experimentally, the same milieus these days were no longer primarily afraid of parochialism and provincialism, but of loss of status (Koppetsch 2013: 8). This led, particularly in a middle-class environment, to self-isolation by withdrawal into exclusive city quarters, which allowed the middle class to remain tolerant and liberal because the actual problems remained on the outside (ibid:: 9). This, according to Koppetsch, revealed a further discrepancy in the claim to superior morality, on the one hand, and the defensive advocacy of vested rights, on the other (ibid.: 13). While the milieu insisted on sustainability and tolerance, the protection of the environment and the inclusion of all, it accepted that low income and migrant population groups were no longer able to afford particular city quarters; while solidarity with the nonprivileged was preached, private schools enjoyed active participation of the children of this education and knowledge milieu (ibid.: 13).

In other studies, it is less the conformity of the middle class that is emphasized, but rather its discomfort with current urban and societal developments. While Susanne Frank, for instance, sees a segregated urban development which, in her words, is characterized by an increasing self-inclusion and isolation of milieus of the knowledge society (Frank 2013 : 41), she observes the interesting situation that relevant shares of those in whose names and for whose requirements the massive social and spatial reconstruction of the inner city is undertaken are no longer happy, and, to a growing extent no longer agree with these developments and particularly with the forces behind them (ibid.). These people reflect their own actions (i.e. decisions about their place of residence and choice of schools) in a highly self-aware manner and, according to Frank, recognize that their actions in central fields of societal coexistence are in conflict with the basic urban attitude which they claim for themselves (ibid.): their emphasis on their conscious decision for an urban lifestyle which is characterized by internationalism, heterogeneity of lifestyles, liveliness and the diversity of cultural offers (see ibid). In this context, in the case of Berlin, Andrej Holm speaks of an uprising of the middle class and a change of urban cultures of protest. While in the past, it had been mainly tenant associations and traditional citizens' initiatives in the affected quarters who protested against a change, today it was also many creative artists and intellectuals who became involved (Holm 2011: 94). These were groups who were small in numbers, but educated and strongly articulated, and who embodied a outright uprising of the middle class (ibid.: 95). A similar thing can now be observed in Munich, for which the Goldgrund example in this contribution stands. However, while Holm argues that, in the case of Berlin, these groups managed to turn their own interests into public affairs (ibid.), this does not apply as readily to the Munich example mentioned above, just as the assessment given by Cornelia Koppetsch regarding a self-isolation of the middle class is not suitable at least for the - relatively large - Goldgrund network. Here, Susanne Frank's observation that the middle class follows the social situations of the city with a certain discomfort and is, therefore, inclined to resistance seems more apt. 


\section{SOCIAL PROTEST}

Something had already become apparent in the first campaign undertaken by the Goldgrund activists which we could observe in different areas of our urban ethics research. It is often a middle class that is intellectual and, in parts, originating from the arts scene (Holm 2011: 94) which becomes active in urban ethical projects. Leading theorists, Henri Lefebvre, David Harvey and Andrej Holm, have already emphasized in the debates around the "right to the city" that cities have always been places of social protest. Goldgrund, by its actions, stands in the tradition of fundamental considerations on subversive politics and similar activist (art) forms which operate under the umbrella term of a communication guerilla. Communication guerilla means different forms of subversive political practice which aim to purloin the signs and codes of the "rulers" and to distort them. Models for this approach range from the Situationist International via the Kulturgeographen to the so-called Culture Jammers (see autonome a.f.r.i.k.a-gruppe, Blisett, and Brünzels 2001: 5ff.). Umberto Eco had already pleaded for a subversive use of signs with his speech on a semiological guerilla as early as 1967 (Eco 1985: 146ff.). Roland Barthes argues in a similar manner when he asked whether it was not the best subversion to distort the codes rather than destroy them (Barthes 1980: 141). The Goldgrund activists take up this idea and have both the ability to mobilize artist and intellectual networks and access the (local) media to make themselves heard. Two of the Goldgrund events may illustrate these 'subversive' practices. In October 2013, the Goldgrund network sent out invitations to a further satirical event in the shape of a grand selling tour for investors, which took place under the motto "Die Zukunft Münchens - wir können nur spekulieren!" [The future of Munich - we can only speculate!]. The tour went past different objects which supposedly or actually were to be renovated or had already been gentrified, such as the former heat and power station of the Munich utility company in the Gärtnerplatzviertel which was sold to private investors and in place of which, a luxury property was being developed. The price per square meter for an owner-occupied apartment in this location was between 9,000 and 14,000 Euro. The tour ended at a Gründerzeit building in Pilotystraße 8, which was also owned by the city and in which only one apartment was occupied. An "office for displaced people" was set up which, for one day, offered a training venue to "homeless" boxers, rehearsal rooms to musicians and studios to artists. ${ }^{23}$ This shopping tour tossed barbs particularly at speculators. Borrowing from the activist group "The Yes Men," characters by the names of Dirk von Staligk (CEO) and Mark Bench (CFO) appeared as representatives of an international team of investors and presented what they called choice objects and reasonably priced delicious morsels of the Munich real estate market. ${ }^{24}$ With such actions, artist practices are used to point to societal and particularly urban problematic situations. This, at least at first sight, contradicts the argument which has increasingly come up in

${ }^{23}$ Oliver Hochkeppel: Stadtführung für Immobilienhaie. In: Süddeutsche Zeitung October 20, 2013, http://www.sueddeutsche.de/muenchen/satire-aktion-in-muenchen-stadtfuehrung-fuer-immobilienhaie-1.1799314 (Accessed December 18, 2016).

${ }^{24}$ http://www.goldgrund.org/wir-koennen-nur-spekulieren/ (Accessed December 19, 2016) 
recent years: that art played such a central role for the capitalist logic of exploitation and productivity that it could no longer stand for a critical position in society. Chantal Mouffe, however, sees the potential of artist practices for contributing to an opposition to the ruling capitalist system. According to her, the establishment of a specific order occurs through hegemonic practices which, in turn, can be challenged by anti-hegemonic practices. In Mouffe's sense, then, there would be no difference between political and apolitical art, because artist practices play a role both in the constitution and the maintenance of a given social order as well as in a challenge to it (Mouffe 2013: 509ff). Jacques Rancière argues in a similar manner by stating that art and aesthetics are political in their essence (Rancière 2007). Mouffe sees one example for this challenge to existing orders in the artist activist practices of the group "The Yes Men", which operates with their strategy of an identity correction (Mouffe 2013: 513) in which they appear under different identities and, for instance, let neoliberal ideologemes (Doll 2008: 254) appear particularly clearly as representatives of the World Trade Organization. They created a stir in their role as official representatives of "Dow Chemical," in which they offered compensation to the victims of the chemical catastrophe in Bhopal and immediately thereafter sent out a counter statement that was also forged in which they emphasized that "Dow Chemical" would not pay compensation and was only accountable to its shareholders (ibid.: 248). ${ }^{25}$

Regarding Goldgrund, aside from the "fake" real estate project and the investor tour, training for brokers also stands in the tradition of such opposition artist practices. Under the heading "Goldgrund Academy - International Immobilien University," they offered a 90-minute training to become a real estate broker, which consisted of three basic modules: M I: Rhetorics: How to sell, how to trick, how to bluff, M II: Immo 24: Copy \& Paste and proper pricing, and M III: In Russian, Arabic, Stock Market Denglish. ${ }^{26}$ In contrast to "The Yes Men," most Goldgrund activities can be recognized as satire more quickly. They also aim much more strongly at a local context than is the case with "The Yes Men". Urban housing problems in a prosperous city such as Munich do not attract the same attention as the activities of the World Trade Organization or Dow Chemical. Arguing with Chantal Mouffe, we, therefore, ask whether the Goldgrund activities can actually be understood as counter-hegemonic interventions which prove the repressive character of the dominant capitalism (Mouffe 2013: 514), or whether they do not rather aim at achieving certain changes within the existing system.

\section{HOUSING AND ETHICAL DEBATES}

Looking at the Goldgrund example, it is interesting that the debate around housing problems is not so much led by social or party political aspects, but that it is more about ethical

\footnotetext{
${ }^{25}$ Martin Doll offers a detailed examination of "The Yes Men", in which he also elaborates on the fake strategies of the group from the perspective of media theory and points to the problematic aspects of this approach (Doll 2008).

26 http://www.bezahlbares-wohnen.de/2015/02/05/am-5-februar-goldgrund-academy-internationalimmobilien-university/ (Accessed December 18, 2016)
} 
issues in the sense of a good and proper life. In this sense, the Goldgrund network primarily positions classical imaginations of urbanity which, in addition to size and density, mainly address diversity and heterogeneity or routine interaction with strangers, subcultures or diverse minorities (Hannerz 1980; Häußermann and Siebel 2004; Sennett 1991; Wüst 2004). This becomes apparent in the statements of the central protagonists of this activist network. Till Hofmann, a creative arts entrepreneur, possibly the main figurehead of this movement, says about all the activities that they aim to create awareness of what it is that makes Munich livable. ${ }^{27}$ Another participant, a cabaret artist, states that letting houses rot away in the city was immoral. ${ }^{28}$ Thus, the argument is not (only) conducted under social aspects, but a finger is pointed at what we comprehend as two understandings of ethics: Firstly, the aspect of reflection and argumentation and, secondly, the focus on a good, successful life to which a certain relationship with other people, the environment and one's own self belong. Goldgrund activists draw the outline of an urban citizen of good conduct and a role model, both directly and indirectly. In Till Hofmann's words: "A city should not speculate with the same means as real estate sharks; this can and must not be - since the city is also us." ${ }^{29}$ As a contribution in the Süddeutsche Zeitung has aptly put it: "With its activities (among other things, a demonstration against the nationalist far-right 'Pegida' movement, which was attended by between 12,000 and 20,000 people), the network creates a kind of social campfire at which the good Munich can warm its hands and pat itself on the back." 30

In their satirical contributions, they distance themselves from those who they feel do not lead a proper urban life, for instance, if a high income riffraff ${ }^{31}$ is denounced or when comedian Franz-Markus Barwasser speaks of a shopping ragtag who was able to spend a lot of money on outrageously expensive apartments which, however, they only needed to put down their shopping bags. ${ }^{32}$ Thus, the activist network creates counter images of the bad, wrong life in the city, which can also be understood as images of an urban ethics failure. With these ascriptions, an aspect emerges which must also be considered in the context of urban ethics. It focuses, in Foucault's sense, on techniques of how people are to become ethical subjects (Butler 2007: 18, 25; Foucault 1987: 277). Therefore, in the context of urban ethics, cultural guiding principles of a "proper" behavior, even a proper existence, are developed which are called upon in the different projects of our research group: the exemplary city dweller and green citizen, the urban cosmopolitan and consumer, the socialist personality, the self-sacrificing subject, the reliable neighbor, the creative citizen and entrepreneur, the networker and so on. Urban ethics prove to be

${ }^{27}$ Anna Fischhaber: Vorübergehend besetzt. In: Süddeutsche Zeitung, October 22, 2013, R4.

${ }^{28}$ Thomas Anlauf: Schluss mit lustig. In: Süddeutsche Zeitung, October 22, 2014, R3.

${ }^{29}$ Anna Fischhaber: Vorübergehend besetzt. In: Süddeutsche Zeitung, October 22, 2013, R4.

30 Kassian Stroh: Politkünstler. In: Süddeutsche Zeitung, November 10, 2015, p. 95.

${ }^{31}$ Stephan Handel: Gruselige Wohnungsnot und fürchterlicher Mietwucher. In: Süddeutsche Zeitung, November 3, 2014, R3.

32 Franz Kotteder: Das Goldgrund-Prinzip. In: Süddeutsche Zeitung, December 27/28, 2014, p. 79. 
fields of discursive practice on which urbanites (are to) constitute themselves as subjects of their own way of life. These actions by Goldgrund are not a mere Munich issue but we can observe similar activities in many (European) cities. ${ }^{33}$ That such artistic and activist missions end in a permanent social engagement, which could be explained with David Graebers concept of social creativity, probably happens less often.

\section{SOCIAL CREATIVITY}

In this sense, the Goldgrund events bring forth those processes of social creativity which we trace in our research on urban ethics. What is important about such processes is that they should not, as other examples from our research group show, be understood as techniques of governance, such as environmental issues in Auckland or the establishment of a Creative City in Singapore, but that they originate in a bottom-up manner, even if, in the Munich example, it is not a powerless milieu that is at the core of it. David Graeber, whom we follow in this context, understands social creativity as the creation of new social forms and institutional arrangements (Graeber 2008: 49) and emphasizes particularly the dimension of action, which is also becoming apparent among the Goldgrund activists. ${ }^{34}$ Social creativity refers especially to ideas about how people should live in a city and banks on the ability of people to institutionalize social relationships which can have different ranges, and encompass both neighborhood initiatives and larger political networks; they can be short-lived or take longer lasting shapes. ${ }^{35}$ The types of social creativity brought into play by Graeber show interconnections with Ulf Hannerz' ideas of urban life. Hannerz conceives of the city as a network of networks, as a web of entanglements of groups of city dwellers which characterizes urban life and which, in its totality, constitutes the city as a social order (Hannerz 1980: 201). Goldgrund shows this character of interconnectedness very well, since the actors are not only part of this activist network, but are also involved in many other networks, such as medial, artist or academic ones. In this sense, in our research group, we understand social creativity as a collective practice in which models of urban coexistence and cooperation are developed which can indeed be of a programmatic nature.

\footnotetext{
${ }^{33}$ Among many examples, I would like to mention the Human Cities project that is being carried out in several European cities and which is co-funded by the Creative Europe Programme of the European Union. The aim of the efforts is to contribute to better sustainable living in cities: http://www. http://humancities.eu/ (Accessed October 28, 2018).

${ }^{34}$ On social creativity as a theoretical perspectivation in our understanding of social ethics, see the following contribution: Eveline Dürr et al.: (under review).

35 In addition to the "Bellevue di Monaco," Goldgrund also remains active in other areas and has, for instance, recently held an event against the building of a supposed noise barrier opposite a refugee accommodation under construction in Neuperlach (https://www.facebook.com/events/675535122614366/) as well as organized a large event for an open society free from fear under the Valentinesque motto "We are all from somewhere" on December 22, 2016 (see https://www.facebook.com/events/168955150244768/ [Accessed December 19, 2016]).
} 
The Goldgrund activists are an example of how, before a milieu-specific background, an attempt is made to realize ideas of a good and proper life in the city not only through artist practices, but also through tangible involvement. In this sense, the actors do not aim at a fundamental reform of societal relationships; rather, they move within the bounds of existing circumstances. It is, therefore, interesting to note which forms of protest Goldgrund does not employ. They intrude into houses and renovate individual apartments to show that demolition is unnecessary or have the static loading of a building calculated. However, there is no squatting involved, because - true to the milieu -fundamental ownership structures are left untouched. In the sense of David Graeber's elaborations, in this manner, they still bring forth new social and cultural forms which do not only serve their own interests, but can also originate from the institutions which, in turn, can form the goals of these activists (Graeber 2008: 50). The foundation of the social cooperative and the project "Bellevue di Monaco" in the buildings in Müllerstraße mentioned above are a representative example of this, because Goldgrund initially aimed for an ethical debate about why there was unused residential space in the center of Munich and about the concern that another gentrification was impending. With the development of their own idea and in networking with other initiatives, the concept of a meeting center developed in which living, refugee work and artist activities could be realized under one roof. While this does not constitute a practical solution for the fundamental problems of insufficient housing space, a lack of artist and rehearsal spaces or shortcomings in refugee care, it can indeed serve as a bellwether for the good and socially engaged Munich.

\section{REFERENCES AND SOURCES}

autonome a.fr.i.l.a-gruppe, Luther Blisett and Sonja Brünzels, eds. 2001. Handbuch der Kommunikationsguerilla. Berlin, Hamburg, Göttingen: Assoziation $A^{4}$.

Barthes, Roland. 1980. Sade, Fourier, Loyola. Paris: Éd. du Seuil.

Beaugrand, Andreas and Pierre Smolarski, eds. 2016. Adbusting. Ein designrhetorisches Strategiehandbuch. Bielefeld: transcript.

Bude, Heinz. 2011. Bildungspanik. Was unsere Gesellschaft spaltet. München: Hanser.

Butler, Judith. 2007. Kritik der ethischen Gewalt. Adorno-Vorlesungen 2002. Frankfurt am Main: Suhrkamp.

Doll, Martin. 2008. "Widerstand im Gewand des Hyper-Konformismus. Die Fake-Strategien von 'The Yes Men'." In Mimikry. Gefährlicher Luxus zwischen Natur und Kultur. Andreas Becker, Martin Doll, Serjoscha Wiemer and Anke Zechner, eds. Schliengen: Ed. Argus, 245-258.

Dürr, Eveline, Moritz Ege, Johannes Moser, Christoph K. Neumann and Gordon M. Winder. 2017. "Urban Ethics. Towards a Research Agenda on Cities, Ethics and Normativity". City, Culture and Society (under review).

Eco, Umberto. 1985. Über Gott und die Welt. Essays und Glossen. München: Hanser.

Foucault, Michel. 1987. "Zur Genealogie der Ethik. Ein Überblick über laufende Arbeiten. Gespräch mit Hubert L. Dreyfus und Paul Rabinow." In Michel Foucault. Jenseits von Strukturalismus und Hermeneutik. Hubert L. Dreyfus and Paul Rabinow, eds. Frankfurt am Main: Athenäum, 268-292. 
Frank, Susanne. 2013. "Unbehagen der Mitte. Die aktuelle Wohnungskrise und die urbanen Mittelschichten". Raumplanung 169/4: 39-43.

Grabka, Markus and Joachim Frick. 2008. "Schrumpfende Mittelschicht. Anzeichen einer dauerhaften Polarisierung der verfügbaren Einkommen?” Wochenbericht des DIW Berlin 10: 101-108.

Graeber, David. 2008. "Fetischismus als soziale Kreativität. Oder: Fetische sind Götter im Prozess ihrer Herstellung". Zeitschrift für Kulturwissenschaften 1: 49-68.

Häußermann, Hartmut and Walter Siebel. 2004. Stadtsoziologie. Eine Einführung. Frankfurt am Main, New York: Campus Verlag.

Hannerz, Ulf. 1980. Exploring the City. Inquiries Toward an Urban Anthropology. New York: Columbia University Press.

Holm, Andrej. 2011. "Das Recht auf die Stadt”. Blätter für deutsche und internationale Politik 8: 89-97.

Koppetsch, Cornelia. 2013. Die Wiederkehr der Konformität. Streifzüge durch die gefährdete Mitte. Frankfurt am Main, New York: Campus Verlag.

Mouffe, Chantal. 2013. "Agonistic Politics and Artistic Practices". In D.A. A Transdisciplinary Handbook of Design Anthropology. Yana Milev, ed. Frankfurt am Main: PL Acad. Research, 508-515.

Rancière, Jacques. 2007. Das Unbehagen in der Ästhetik. Wien: Passagen-Verlag.

Sennett, Richard. 1991. Civitas. Die Großstadt und die Kultur des Unterschieds. Frankfurt am Main: S. Fischer.

Wüst, Thomas. 2004. Urbanität. Ein Mythos und sein Potential. Wiesbaden: VS, Verlag für Sozialwissenschaften.

\section{PROSVJEDI I DRUŠTVENA KREATIVNOST: MREŽA UMJETNIKA I AKTIVISTA UNAPREĐUJE RASPRAVU O PROBLEMIMA URBANOG ŽIVOTNOG PROSTORA}

Ovaj je rad nastao u okvirima projekta "Stanovanje i politika stanovanja" u Münchenu, što je potprojekt istraživačke skupine DFG-a “Urbana etika”. Na temelju primjera mreže umjetnika i aktivista Goldgrund u radu se pokazuje kako dionici iz srednje klase reagiraju na napeto tržište nekretnina i iznajmljivača u Münchenu prosvjedujući na različite načine. Primjerice, Goldgrund je osmislio nepostojeće projekte razvoja nekretnina, igrao aktivnu ulogu u privatizaciji javnog vlasništva te je osnovao socijalnu zadrugu "Bellevue di Monaco". U članku se njihova djelatnost analizira na različitim razinama. Rad započinje analizom uloge srednje klase u sličnim aktivističkim pokretima te se bavi pitanjem što motivira njihovo sudjelovanje. Zatim se analiziraju "subverzivne" prakse ove vrste protesta. Nadalje, u članku se raspravlja o etičkim argumentima koje mreža Goldgrund upotrebljava, a koji ističu dobar život u gradu i empatični urbanizam. Članak završava interpretacijom djelatnosti mreže kao i osnutka socijalne zadruge kao oblika “društvene kreativnosti” kako je definira David Graeber, a koja doprinosi stvaranju novih društvenih oblika i institucionalnih ustroja.

Ključne riječi: tržište nekretnina, protestni pokreti, srednja klasa, društvena kreativnost, urbana etika, München 